\title{
INFLUENCE OF BASIL OIL AS AN ESSENTIAL OIL ON BUFFALO CALVES PERFORMANCE, DIGESTIBILITY, HAEMOBIOCHEMICAL PROFILE AND RUMEN FERMENTATION INDICATORS
}

\author{
A. A. Marwan ${ }^{1}$ and S. A. Mousa ${ }^{2}$ \\ ${ }^{1}$ Animal Production Dept., Fac. of Agric., Ain Shams Univ., Egypt. \\ ${ }^{2}$ Department of medicine and infectious diseases, Faculty of Veterinary Medicine, Cairo Univ., Egypt. \\ Corresponding author: Ahmed Marwan; E-mail: ahmed_marwan97@yahoo.com
}

(Received 12/7/2021, accepted 9/8/2021)

\section{SUMMARY}

$\mathrm{T}$ This work was fulfilled to assess the effect of supplementation diets with Basil oil in buffalo calves on growth performance criteria, rumen fermentation properties and certain biochemical indices. A total number of 18 buffalo calves of (4-6) months age and $141.29 \mathrm{~kg}$ average body weight were classified randomly into three equal groups (6 animals each): Animals of T1 (control) were fed on basal diet and those of T2 and T3 (treated) were fed as T1 plus 2 and $4 \mathrm{ml}$ basil oil (BO) per head daily, respectively. This experiment was expanded for fifteen weeks. Blood plasma and rumen liquor Samples were obtained from all experimental animals in all groups at the finishing of study for detecting certain blood biochemical parameters and rumen fermentations properties. Results showed that the groups supplemented by basil oil (T2 and T3) recorded significant improvement $(\mathrm{P} \leq 0.05)$ in $\mathrm{DM}$ intake, digestibility, growth performance and best feed conversion ratio compared with control group (T1). Also, treated groups (T2 and T3) recorded non observable $(\mathrm{P} \geq 0.05)$ effects in TVFA's, total protozoa count (TPC) and ammonia concentration compared with control group. Blood plasma analysis in supplemented groups (T2 and T3) showed significant improvement $(\mathrm{P} \leq 0.05)$ in protein profile (total protein and albumin), nonsignificant decrease in urea, creatinine, triglycerides, liver function enzymes levels in comparing with control group. The results collected from this study proposed that buffalo calves fed diets supplemented with basil oil as an essential oil, showed greater total weight gains, daily weight gains, and feed conversion rates with better rumen fermentation parameters.

Keywords: Buffalo calves, Basil oil (BO), rumen fermentation, digestibility, biochemical profile and growth performance.

\section{INTRODUCTION}

Numerous endeavors in the sector of animal nutrition were done to accomplish an expansion in animal production. Feed additives are great subjects that can enhance utilization and the efficiency of feed and animal production (Abdou, 2001)

The use of low levels of antibiotics in Animal's diets and improvement of growth in animal production, has turned out to be progressively questionable because of the effect for residues in meat and milk. Accordingly, animal researchers are effectively looking for choices to these additives. Plant extracts, for example essential oils (EO), are components that can be used as natural feed additives in ruminant nutrition (Yang et al., 2010). Moreover, Magi and Sahk (2003) stated that herbal medicine is a growing area of alternative medicine nowadays. Many of the active ingredients in produced medications are gotten initially from plant mixes and have a wide scope of utilization. It is accepted that plants are more natural, less poisonous, and more secure than compound arrangements.

Many of medicinal herbs and plants act as antibacterial agent against harmful microorganisms, antiseptic and anti-inflammatory, which attributed to the functional materials (Mahran, 1967, Hmamouchi et al., 1992 and Tozyo et al., 1994). Moreover, some studies showed that these plants had 


\section{Marwan and Mousa}

great impact on digestibility, weight gain and efficiency of feed with cow (Singh and Taparia, 1992 and Castro et al., 1995).

Essential oils (EO) are volatile aromatic substance have oily characteristics and these oils derived and extracted from plants (Calsamiglia et al., 2007). Plant EO show a great effectiveness as antimicrobial agent (Burt, 2004) and have achieved interest as a feasible natural alternate for antibiotic modifiers of fermentation in rumen because of the expansion in open worry over anti-microbial deposits and opposition.

Essential oils (EO) are used as natural replacement of antibiotics, enhancing growth, feed efficiency and preventing future health damage to consumers, derived from residues of antibiotics (Ornaghi et al., 2017). So, this work was fulfilled to evaluate the impact of adding basil oil (BO) as an essential oil in buffalo calves diets on performance, digestibility, rumen fermentation and certain biochemical indices.

\section{MATERIALS AND METHODS}

This study was done in the Experimental Research Station belongs to Faculty of Agriculture, Ain Shams University located in Shalakan village, Qalubia Governorate, Egypt.

\section{Feed additives composition and sources:}

Basil Oil (BO):

Ocimum basilicum L., also known as sweet basil, belongs to family Lamiaceae. This crop is very important industrially essential oil producing and grown in numerous regions around the world (Sajjadi, 2006). Main essential oils which isolated from these plants were used in flavoring agent in food and perfumes industry Telci et al. (2006). Recently, the prospect uses of Ocimum basilicum essential oil as antioxidant and antimicrobial agents have been studied (Politeo et al., 2007, Suppakul et al., 2003 and Hussain et al., 2008).

\section{The experimental animals and rations:}

Eighteen growing buffalo calves of (4-6) month's age and $141.29 \mathrm{~kg}$ body weight were distributed into three similar groups (6 animals each). Each group was classified randomly to feed according to farm system regime (NRC, 2001), plus experimental treatments as following:

$\mathrm{T} 1$; fed control diet (control group)

$\mathrm{T} 2$; were fed as $\mathrm{T} 1$ group plus $2 \mathrm{ml} \mathrm{BO} / \mathrm{head} /$ day.

$\mathrm{T} 3$; were fed as $\mathrm{T} 1$ group plus $4 \mathrm{ml} \mathrm{BO} / \mathrm{head} /$ day.

All animals were fed on diet containing concentrate feed mixture (CFM), berseem and wheat straw. The CFM consisted of $15 \%$ soybean meal, $38 \%$ ground maize, $5 \%$ rice bran, $34 \%$ wheat bran, $2 \%$ limestone powder, $1 \%$ mineral salts, $3 \%$ molasses, $1 \%$ sodium chloride and $1 \%$ sodium bicarbonate.

Overall means of the initial body weights of the experimental calves were $123.20,163.33$ and 137.33 Kg for T1, T2 and T3, respectively. The experiment was prolonged for fifteen weeks since the animals introduced to the treatment, experimental data was collected during the entire period. Chemical compositions of feed stuff are presented in Table (1).

\section{Digestibility trials:}

Digestibility trials were carried out for all experimental animals using a grab sample method according to Schneider and Flatt (1975), where acid insoluble ash

\section{Blood samples:}

Blood samples were collected from jugular vein from all calves monthly. These samples were collected into a clean dried tubes with EDTA. Plasma samples were obtained by centrifuging at 4000 (rpm) for 15 minutes, that for determination of selected biochemical analysis.

\section{Blood plasma analysis:}

Blood plasma was analyzed for Total protein (Armstrong and Carr 1964), albumin (Doumas et al., 1971), urea (March, 1965), creatinine (Husdan, 1968), GPT and GOT (Reitman and Frankel 1957), and triglyceride (Fassati, 1982): Globulin was calculated by difference. 
Egyptian J. Nutrition and Feeds (2021)

Table (1) Chemical composition of feed stuffs (DM basis).

\begin{tabular}{lrrrrrrrr}
\hline Feed stuff & DM & OM & CF & CP & EE & NFE & Ash & **AIA \\
\hline Berseem & 90.94 & 95.38 & 30.15 & 19.64 & 3.80 & 41.79 & 4.62 & 4.42 \\
Wheat straw & 91.73 & 81.66 & 51.92 & 4.15 & 1.83 & 23.76 & 18.34 & 15.31 \\
CFM* & 91.56 & 96.24 & 23.60 & 16.88 & 2.99 & 52.77 & 3.76 & 5.62 \\
\hline
\end{tabular}

* CFM: Concentrate feed mixture.

**AIA: Acid insoluble ash.

(AIA) was applied for determining the nutrients digestibility as a natural internal marker.

\section{Productive performance parameters:}

Live body weights were individually recorded at two weeks intervals. The average daily body weight gain was individually calculated. Daily feed intake was determined for each replicate of a treatment by the difference between the daily offered feed and the daily residual one. Feed conversion ratios were obtained by dividing the amount of feed consumption per calf by the corresponding weight gain in a certain stage (two weeks).

\section{Analytical methods:}

The samples of feedstuffs and feaces were analyzed to determine the chemical composition by using the AOAC (1995) procedure to determine moisture, dry matter, organic matter, crude protein, crude fiber, ether extract and ash contents, while nitrogen free extract (NFE) content was calculated by difference.

\section{Statistical Analysis:}

The data obtained were statistically analyzed using (SAS) (2001). Separation among means were detected by using Duncan multiple tests (1955).

\section{RESULTS AND DISCUSSION}

\section{Dry matter intake:}

Results presented in Table (2) showed the impact of adding basil oil (BO) on dry matter intake. Data showed an increase $(\mathrm{P} \leq 0.05)$ on $\mathrm{DMI}$ by adding $\mathrm{BO}$ on the basic ration in both experimental groups (T2 and T3) in comparing with control one (T1). Data also showed that the highest DMI value was recorded for the treated group by $2 \mathrm{ml} \mathrm{BO}$ daily (T3) vs the other groups.

Table (2): Effect of Basil oil supplementation on dry matter intake (kg/h/d).

\begin{tabular}{lccc}
\hline \multirow{2}{*}{ Day } & \multicolumn{3}{c}{ Treatments } \\
\cline { 2 - 4 } & $\mathrm{T} 1$ & $\mathrm{~T} 2$ & $\mathrm{~T} 3$ \\
\hline $0-15$ & $4.23 \pm 0.67$ & $4.70 \pm 0.89$ & $5.47 \pm 0.54$ \\
$16-30$ & $4.21 \pm 0.51$ & $4.82 \pm 0.24$ & $5.60 \pm 1.12$ \\
$31-45$ & $4.30 \pm 0.57$ & $4.90 \pm 0.95$ & $5.66 \pm 0.73$ \\
$46-60$ & $4.31 \pm 0.38$ & $5.01 \pm 0.93$ & $5.79 \pm 0.54$ \\
$61-75$ & $4.43 \pm 0.66$ & $5.15 \pm 0.20$ & $5.90 \pm 1.16$ \\
$76-90$ & $4.49 \pm 0.69$ & $5.27 \pm 0.98$ & $6.01 \pm 0.76$ \\
$91-105$ & $4.46 \pm 0.53$ & $5.37 \pm 0.96$ & $6.14 \pm 0.55$ \\
Average & $4.35^{\mathrm{C}}$ & $5.03^{\mathrm{B}}$ & $5.80^{\mathrm{A}}$
\end{tabular}

$A, B$ and $C$ : means in the same row followed by different superscripts differed significantly at $(P \leq 0.05)$.

T2: were fed as the control one plus $2 \mathrm{ml}$ BO/head/day.

T3: were fed as the control one plus $4 \mathrm{ml}$ BO/head/day. 
These finding are in agreement with those recorded by Ornaghi et al. (2017) on crossbred bulls (Brown Swiss*Nellore). They fed calves on basal diet supplemented by different doses of cinnamon as an essential oil. They reported that DM intake was improved linearly $(\mathrm{P}<0.05)$ in treated young bulls. Moreover, Yang et al. (2010), fed growing heifers on high level of concentrate diets supplemented by Eugenol oil (EUG) as an essential, using treatments as follow: control (no EUG added); $400 \mathrm{mg} / \mathrm{d}$ EUG; $800 \mathrm{mg} / \mathrm{d}$ EUG; and $1600 \mathrm{mg} / \mathrm{d}$ EUG oil. They found that the amount of feed intake was increased with great dose of the essential oil. Also, same findings were recorded by Benchaar et al. (2006a) on beef cattle, when they supplemented diets by essential oil in a mixture form containing Eugenol. On contrary, Khorrami et al. (2015) on Holstein steers ruminally cannulated fed basal diet supplemented by thyme oil and cinnamon oil as an essential oils. They reported that DM intake was not improved by additives.

The present results may be explained by the partly increase of palatability and appetite of the diets as a result of adding Basil oil.

\section{Nutrients digestibility:}

Data of digestion coefficient of dietary treatments are illustrated in Table (3). Digestion coefficients of DM, OM, CP, CF, EE and NFE were improved $(\mathrm{P} \leq 0.05)$ for animals fed diets supplemented by $\mathrm{BO}$ as an essential oil (T2 and T3) compared with those fed basal diet only (T1). The best values of digestibility coefficients $(\mathrm{P} \leq 0.05)$ of the previous deferent nutrients were recorded in T3 followed by T2 (treated groups) and the lowest values were recorded for T1 (control group). These findings are in harmony with those obtained by Marwan (2008), when he fed suckling buffalo calves on basal diet supplemented by black seed oil (Nigella sativa) as an essential oil. He found an enhancement in digestibility coefficient for all nutrients in treated calves. In the same trend, Malekkhahi et al. (2015) recorded an improvement $(\mathrm{P} \geq 0.05)$ in $\mathrm{DM}, \mathrm{OM}$ and $\mathrm{CP}$ digestibility, when they fed growing lambs with diets supplemented by mixture of essential oil. Also, Meschiatti et al. (2019) on cannulated Nellore steers, found an increase in crude protein digestibility for animals received diets supplemented by a blend of EO in comparing with steers received control diet. On contrary, Khorrami et al. (2015) stated that the nutrients digestibility were not affected by adding essential oils (thyme oil and cinnamon oil) on ruminally cannulated Holstein steers.

Table (3): Effect of Basil oil supplementation on the nutrients digestibility coefficients of the buffalo calves.

\begin{tabular}{lccc}
\hline Item & $\mathrm{T} 1$ & $\mathrm{~T} 2$ & $\mathrm{~T} 3$ \\
\hline $\mathrm{DM}$ & $61.68 \pm 1.06^{\mathrm{B}}$ & $66.26 \pm 1.28^{\mathrm{A}}$ & $68.57 \pm 1.43^{\mathrm{A}}$ \\
$\mathrm{OM}$ & $67.88 \pm 1.07^{\mathrm{C}}$ & $71.42 \pm 1.18^{\mathrm{B}}$ & $74.56 \pm 0.38^{\mathrm{A}}$ \\
$\mathrm{CP}$ & $63.15 \pm 0.41^{\mathrm{B}}$ & $67.07 \pm 0.96^{\mathrm{A}}$ & $68.62 \pm 0.31^{\mathrm{A}}$ \\
$\mathrm{CF}$ & $59.22 \pm 2.26^{\mathrm{B}}$ & $61.77 \pm 1.62^{\mathrm{AB}}$ & $63.40 \pm 0.31^{\mathrm{AB}}$ \\
$\mathrm{EE}$ & $78.79 \pm 1.19^{\mathrm{B}}$ & $82.94 \pm 0.87^{\mathrm{A}}$ & $84.71 \pm 0.09^{\mathrm{A}}$ \\
$\mathrm{NFE}$ & $71.97 \pm 0.73^{\mathrm{C}}$ & $74.34 \pm 0.72^{\mathrm{B}}$ & $78.01 \pm 0.12^{\mathrm{A}}$ \\
\hline
\end{tabular}

$A, B$ and $C:$ means in the same row followed by different superscripts differed significantly at $(P \leq 0.05)$.

\section{Rumen fermentation properties:}

It is of interest to notice that all control and treated animals recorded similar values of ruminal $\mathrm{pH}$, TVFAS and ammonia $(\mathrm{P} \geq 0.05)$. However total protozoa count (TPC) showed significant gradual reduction as the level of basal oil increased (Table 4).

Rumen $\mathrm{pH}, \mathrm{NH} 3-\mathrm{N}$ and VFA concentrations are great indicated that reflect rumen performance and stability of the intra ruminal milieu. In this study, oral administration of basil oil with different doses $(2$ and $4 \mathrm{ml} \mathrm{BO/head/day)} \mathrm{not} \mathrm{affect} \mathrm{the} \mathrm{rumen} \mathrm{pH}$ the same finding was recorded by Chaves et al. (2011) who recorded no differences in ruminal $\mathrm{pH}$ after supplementing various doses $(0,100,200$ and 400 $\mathrm{mg} / \mathrm{kg} \mathrm{DM}$ ) of cinnamaldehyde to the diet of growing lambs. Ruminal $\mathrm{pH}$ was not affected with basil oil compared to control which is in harmony with previous findings in beef cattle (Yang et al., 2010a; Geraci et al., 2012; Vakili et al., 2013; Khorrami et al., 2015). 
Egyptian J. Nutrition and Feeds (2021)

Table (4): Effect of Basil oil supplementation on some rumen fermentation parameters.

\begin{tabular}{lccc}
\hline \multirow{2}{*}{ Item } & \multicolumn{3}{c}{ Treatment } \\
\cline { 2 - 4 } & $\mathrm{G} 1$ & $\mathrm{G} 2$ & $\mathrm{G} 3$ \\
\hline $\mathrm{pH}$ & 6.81 & 6.79 & 6.80 \\
TVFAS (mmol/l) & 80.14 & 79.13 & 79.36 \\
Amm (mmol/l) & 100.87 & 101.30 & 102.49 \\
TPC & $15.67^{\mathrm{B}}$ & $10.80^{\mathrm{A}}$ & $11.68^{\mathrm{C}}$ \\
\hline
\end{tabular}

A, $B$ and $C:$ means in the same row followed by different superscripts differed significantly at $(P \leq 0.05)$.

The present result of ruminal ammonia concentration is in harmony with that reported by Khiaosaard and Zebeli (2013). In vitro different studies results have shown that the impact of essential oil and their functional compounds on ruminal NH3-N concentration are dose-dependent and, further, that these main compounds when used at high doses are more efficient than low doses.

Essential oils could improve metabolism of protein and reduce levels of rumen ammonia and lead to an increasingly effective use of dietary nitrogen by hindering deamination, i.e., the breakdown of amino acids to NH3, conceivably through the particular confinement of the movement of a specific group of bacteria inside the rumen, the hyper ammonia creating (HAP) bacterial at the degree of connection and colonization (McIntosh et al., 2003 and Calsamiglia et al., 2007).

The present results of TVFAS concentration are agree with those observed by Khorrami et al., (2015) in steers Ratika and singh (2018). In few studies, supplementing diets by EO was increased ruminal VFA concentration. Castillejos et al. (2005) showed that addition of $1.5 \mathrm{mg} / \mathrm{l}$ essential oil mixture increased TVFA concentration.

The decrease $(\mathrm{P} \leq 0.05)$ in TPC in basil oil supplemented groups compared with control group agree with that reported by Khorrami et al. (2015) in steers. Santoro et al. (2007) illustrated that antiprotozoal impacts of EO may be attributed to its hydrophobicity, which saturates the cell layer of protozoa and meddles with the cytosolic metabolic pathways.

\section{Blood plasma parameters:}

Data of Table (5) showed significant increase $(\mathrm{P} \leq 0.05)$ in total protein, albumin and globulin, while there were non-significant decrease in BUN (Blood urea nitrogen), triglycerides, AST, ALT and creatinine levels in basil oil groups (T2 and T3) in comparing with those in control one (T1). The values in all experimental groups were within normal physiological ranges (Kaneko et al., 1997). The same results were recorded by Malekkahi et al. (2015) in lambs, Davidson et al. (2003) and Yang et al. (2010) in beef cattle. In this area, Kumar et al. (1980) and Bush (1991) illustrated that serum total proteins concentration reflects the nutritional grade of the animal and it has a great link with dietary protein level.

In kidney function attributes, basil oil supplemented group had numerically lower levels of urea and creatinine in the blood plasma. The same results were mentioned by Malekkahi et al. (2015) in lambs, yang et al. (2010) in beef cattle. These results might be attributed to that Urea-N concentration in the blood is highly correlated with ruminal NH3-N concentration (Petit and Flipot, 1992; Davidson et al., 2003). As ruminal NH3- N concentration was not found to be affected by basil oil supplementations in our study, no change would be expected to occur in plasma urea-N concentration. So, supplementation had no opposing impacts on glomerular filtration, thus safe for renal functioning. These results of nonsignificant impacts of basil oil on plasma BUN and creatinine in this study are in accordance with those results obtained by Yang et al. (2010) in beef cattle.

Among the indicators of liver functioning activity, AST and ALT were non decreased $(\mathrm{P} \geq 0.05)$ in treated group in comparing with those in control group although the values in all the groups were within normal physiological ranges (Kaneko et al., 1997). Values of AST and ALT activity in this study indicate normal activity of the animal hepatic tissues, consequently, basil oil application in the present study had no harmful effects on the liver activity. Moreover, yang et al. (2010) reveal that adding essential oil to beef's diets had not any major adverse influence on blood parameters. 
Table (5): Effect of Basil oil supplementation on selected blood plasma biochemical parameters.

\begin{tabular}{|c|c|c|c|}
\hline \multirow{2}{*}{ Item } & \multicolumn{3}{|c|}{ Treatment } \\
\hline & $\mathrm{T} 1$ & $\mathrm{~T} 2$ & T3 \\
\hline Total protein $(\mathrm{g} / \mathrm{dl})$ & $5.93^{C}$ & $6.26^{\mathrm{B}}$ & $6.46^{\mathrm{A}}$ \\
\hline Albumin (g/dl) & $1.98^{\mathrm{C}}$ & $2.21^{\mathrm{A}}$ & $2.13^{\mathrm{B}}$ \\
\hline Globulin (g /dl) & $3.94^{\mathrm{B}}$ & $4.05^{\mathrm{B}}$ & $4.33^{\mathrm{A}}$ \\
\hline Urea (mg /dl) & $28.25^{\mathrm{A}}$ & $27.63^{\mathrm{A}}$ & $26.14^{\mathrm{A}}$ \\
\hline Creatinine (g/dl) & $1.28^{\mathrm{A}}$ & $1.27^{\mathrm{A}}$ & $1.26^{\mathrm{A}}$ \\
\hline Triglyceride (mg/dl) & $36.99^{\mathrm{A}}$ & $34.98^{\mathrm{A}}$ & $35.85^{\mathrm{A}}$ \\
\hline AST (unit /L) & $31.50^{\mathrm{A}}$ & $30.17^{\mathrm{A}}$ & $29.33^{\mathrm{A}}$ \\
\hline ALT (unit /L) & $30.11^{\mathrm{A}}$ & $29.08^{\mathrm{A}}$ & $28.25^{\mathrm{A}}$ \\
\hline
\end{tabular}

$A, B$ and $C$ : means in the same row followed by different superscripts differed significantly at $(P \leq 0.05)$.

Regarding to the level of triglycerides in experimental group showed non-significant decrease although the values in all experimental groups were within normal physiological ranges in buffalo calves (Kaneko et al., 1997). Same results were recorded by Malekkahi et al. (2015) in lambs, yang et al. (2010) in beef cattle.

\section{Body weight and growth performance criteria:}

Results clearly showed the positive significant (table 6) effect of basil oil as an essential oil on total and daily gain of supplementing diet in comparing with control group.

The higher values $(\mathrm{P} \leq 0.05)$ of average daily gain and total gain were recorded for groups received basil oil with diets (T2 and T3) than the control group (T1). This may be explained by, 1) the higher DM intake for the treated groups than the control group (table 2). 2) The better digestibility which recorded for basil oil supplemented groups T2 and T3 (Table 3), that was led to enhance the absorbed nutrients, consequently increase body weight gain. 3) Increased protein anabolism due to higher protein digestibility which led to higher blood plasma total protein and albumin concentration, which result an increase in protein biosyntheses, and decrease protein catabolism, and led to decrease blood urea concentration in these groups (Table 5).

Table (6): Effect of Basil oil supplementation on changes of body weights and daily gain (kg/h/d).

\begin{tabular}{lccc}
\hline \multirow{2}{*}{ Item } & \multicolumn{3}{c}{ Treatment } \\
\cline { 2 - 4 } & $\mathrm{T} 1$ & $\mathrm{~T} 2$ & $\mathrm{~T} 3$ \\
\hline Animal weight & & & \\
Initial weight & $123.20 \pm 16.25$ & $163.33 \pm 22.51$ & $137.33 \pm 22.52$ \\
Final weight & $183.60 \pm 19.58$ & $243.67 \pm 21.49$ & $220.33 \pm 23.55$ \\
Total gain & $60.40 \pm 3.44^{\mathrm{B}}$ & $80.33 \pm 3.84^{\mathrm{A}}$ & $83.00 \pm 2.64^{\mathrm{A}}$ \\
Days & & Average daily gain $(\mathrm{kg} / \mathrm{h} / \mathrm{day})$ & \\
$0-15$ & $0.573 \pm 0.07$ & $0.711 \pm 0.16$ & $0.689 \pm 0.16$ \\
$16-30$ & $0.560 \pm 0.05$ & $0.667 \pm 0.10$ & $0.733 \pm 0.08$ \\
$31-45$ & $0.560 \pm 0.08$ & $0.778 \pm 0.09$ & $0.822 \pm 0.12$ \\
$46-60$ & $0.533 \pm 0.03$ & $0.778 \pm 0.12$ & $0.800 \pm 0.13$ \\
$61-75$ & $0.560 \pm 0.10$ & $0.733 \pm 0.10$ & $0.755 \pm 0.12$ \\
$76-90$ & $0.573 \pm 0.12$ & $0.800 \pm 0.10$ & $0.822 \pm 0.16$ \\
$91-105$ & $0.667 \pm 0.11$ & $0.889 \pm 0.10$ & $0.911 \pm 0.10$ \\
Average & $0.575^{\mathrm{B}}$ & $0.765^{\mathrm{A}}$ & $0.790^{\mathrm{A}}$ \\
\hline A and $B:$ means in the same row followed by different superscripts differed significantly at $(P \leq 0.05)$.
\end{tabular}


Natural additives can possibly adjust rumen fermentation and enhance animal productivity (Fandiño et al., 2008; Geraci et al., 2012; Valero et al., 2014).

These results in harmony with those obtained by Ornaghi et al. (2017) when they fed crossbred bulls (Brown Swiss*Nellore) on diets supplemented by cinnamon.

Oil as an essential oil. In addition, Meschiatti et al. (2019) recorded an enhancement in average daily gain in Nellore bulls fed on diets supplemented by mixture of essential oil. Moreover, Compiani et al. (2013) reported an improvement in average daily gain on Charolais beef cattle received mixture of (cinnamaldehyde, eugenol, and capsicum) as an essential oil.

\section{Feed conversion ( $\mathrm{kg} \mathrm{DM/} \mathrm{kg} \mathrm{gain):}$}

Results of dry matter conversion were tabulated in Table (7). The data showed that the better $(\mathrm{P} \leq 0.05) \mathrm{DM}$ conversion was recorded for the calves received $\mathrm{BO}$ as an essential oil (T2 and $\mathrm{T} 3$ ) compared with the control one (T1). This may be attributed to the Basil oil as an essential oil may be having a stimulating impact on the rumen.

Table (7): Effect of Basil oil supplementation on dry matter conversion (kg DM/ kg gain).

\begin{tabular}{lccc}
\hline Day & \multicolumn{3}{c}{ Treatment } \\
\cline { 2 - 4 } & $\mathrm{T} 1$ & $\mathrm{~T} 2$ & $\mathrm{~T} 3$ \\
\hline $0-15$ & $7.54 \pm 0.83$ & $8.53 \pm 2.40$ & $7.11 \pm 1.30$ \\
$16-30$ & $7.57 \pm 0.79$ & $8.37 \pm 0.79$ & $6.79 \pm 1.06$ \\
$31-45$ & $8.18 \pm 1.35$ & $7.22 \pm 0.58$ & $6.01 \pm 0.83$ \\
$46-60$ & $8.07 \pm 0.52$ & $7.71 \pm 1.50$ & $6.43 \pm 1.35$ \\
$61-75$ & $8.78 \pm 1.60$ & $8.02 \pm 0.77$ & $7.30 \pm 1.58$ \\
$76-90$ & $8.38 \pm 0.93$ & $7.63 \pm 1.27$ & $6.47 \pm 0.48$ \\
$91-105$ & $7.18 \pm 0.98$ & $7.01 \pm 1.07$ & $5.81 \pm 0.61$ \\
Average & $7.96^{\mathrm{A}}$ & $7.78^{\mathrm{A}}$ & $6.56^{\mathrm{B}}$ \\
\hline
\end{tabular}

$A$ and $B$ : means in the same row followed by different superscripts differed significantly at $(P \leq 0.05)$.

Proper functions and digestion (Table 3), which led to more increase the absorbed nutrients, consequently led to more body weight gain (Table 6).

These results are agree with those reported by Tassoul and Shaver (2009) on Holstein cows fed diets supplemented by mixture of essential oil. They found an enhancement in feed efficiency. Also Malekkhahi et al. (2015) recorded an improvement $(\mathrm{P} \geq 0.05)$ in feed efficiency on growing lambs fed diets supplemented by mixture of essential oil. Moreover, Valero et al. (2014) found an enhancement in feed efficiency on bulls fed diets supplemented by essential oils (cashew and castor oils).

\section{CONCLUSION}

The obtained results from this study suggested that supplementation of buffalo calves with basil oil as a rate of 2 and $4 \mathrm{ml} / \mathrm{h} / \mathrm{d}$ improved dry matter intake, nutrients digestibility, total weight gains, daily weight gains, feed conversion rates and rumen fermentation parameters and the best results were recorded for $4 \mathrm{ml}$ dose. 


\section{Marwan and Mousa}

\section{REFERENCES}

AOAC (1995). Official methods of analysis. 15th ed. Association of Official Analytical Chemists. Arlongton, Virginiall, USA.

Abdou M M.(2001). Effect of some medicinal plants in the ration on productive performance of lactating animals. Ph. D. Thesis, Fac. of Agric. Ain Shams Univ. Cairo, Egypt.

Armstrong W D and C W Carr (1964). Physiological chemistry $3^{\text {rd }}$ ed. P, 75. Burges Publishing Co. Minneapolis, Minnesota.

Benchaar, C., Duynisveld, J.L., Charmley, E. (2006a). Effects of monensin and increasing dose levels of a mixture of essential oil compounds on intake, digestion and growth performance of beef cattle. Can. J. Anim. Sci., 86: 91-96.

Burt S. (2004). Essential oils: Their antibacterial properties and potential applications in foods - A review. Int. J. Food Microbiol., 94:223-253.

Bush B.M. (1991). Interpretation of Laboratory Results for Small Animal Clinicians. Oxford Blackwell Scientific Publications, London.

Calsamiglia S. M., Busquet P. W., Cardozo L, Castillejos, and A Ferret (2007). Invited review: Essential oils as modifiers of rumen microbial fermentation. J. Dairy Sci., 90:2580-2595.

Castillejos L, Calsamiglia S, Ferret A, Losa R. (2005). Effects of a specific blend of essential oil compounds and the typeof diet on rumen microbial fermentation and nutrient flow from a continuous culture system. Animal Feed Science and Technology, 119: 29-41.

Castro F B, T C B Paiva and J R Arcaro (1995). Substitution of sugar cane with steam-treated eucalyptus (Eucalyptus grandis): effect on intake and growth rate of dairy heifers. Anim. feed Sci. and Technology, 52: 93-100.

Chaves A V, Dugan M E R, Stanford K, Gibson L L, Bystrom J M, McAllister T A, Van Herk F, Benchaar C. (2011). A dose-response of cinnamaldehyde supplementation on intake, ruminal fermentation, blood metabolites, growth performance, and carcass characteristics of growing lambs. Livestock Science, 141: 213-220.

Compiani R, Sgoifo Rossi C A, Pizzi A, Dell'Orto V. (2013). Administration of Essential Oils Cinnamaldehyde, Eugenol, and Capsicum to Beef Cattle: Effects on Health Status and Growth Performance. In: Boiti C., Ferlazzo A., Gaiti A., Pugliese A. (eds) Trends in Veterinary Sciences. Springer, Berlin, Heidelberg.

Davidson S, Hopkins B A, Diaz D E, Bolt S M, Brownie C, Fellner V, Whitlow L W. (2003). Effects of amounts and degradability of dietary protein on lactation, nitrogen utilization, and excretion in early lactation Holstein cows. Journal of Dairy Science, 86: 1681-1689.

Doumas B, W Wabson and H Biggs (1971). Albumin standards and measurement of serum with bromocresol green, clin. Chem.. Acta., 31:87.

Duncan David B. (1955). Multiple range and multiple F test. Biometric, 11: 1-42.

Fandiño I, Calsamiglia S, Ferret A, Blanch M. (2008). Anise and capsicum as alternatives to monensin to modify rumen fermentation in beef heifers fed a high concentrate diet. Anim. Feed Sci. Technol., 145: 409-417.

Fassati P, and Principe L. (1982). Measurement triglyceride. Clin . Chem., 28: 2077

Fivevet GMP-WHO (2017). http://www.fivevet.vn, Ha Binh Phuong Industrial Zone - Hanoi - Vietnam.

Geraci J I, Garciarena A D, Gagliostro G A, Beauchemin K A, Colombatto D, 2012. Plant extracts containing cinnamaldehyde, eugenol and capsicum oleoresin added to feedlot cattle diets Ruminal environment, short term intake pattern and animal performance. Anim. Feed Sci. Technol., 176: 123-130.

Hmamouchi M, Bendai M, Zouhdi M, Agoumi A, and Peiccuer J. (1992). Chemical and microbiological studies of essential oils of Moroccan Eucalyptus species. Revue de Medecines et Pharmacopees, Africaines, 6:2, 109-117. 
Husdan, H. (1968). Chemical determination of creatinine with depproteinization. Clin. Chem., 14: 222.

Hussain A I, Anwar F, Sherazi S T H, Przybylski R. (2008). Chemical composition, antioxidant and antimicrobial activities of basil (Ocimum basilicum) essential oils depends on seasonal variations Food Chem., 108 (2008), pp. 986-995.

Kaneko JJ, Harvey JW and Bruss ML. (1997). Clinical Biochemistry of Domestic Animals, 5th edn. Academic Press, San Diego, California, USA.

Khiaosa-ard R, and Zebeli, Q, (2013). Meta-analysis of the effects of essential oils and their bioactive compounds on rumen fermentation characteristics and feed efficiency in ruminants. J. Anim. Sci., 91: 1819-1830.

Khorrami B, Vakili A R, Danesh Mesgarana M, Klevenhusen F. (2015). Thyme and cinnamon essential oils: Potential alternatives for monensin as a rumen modifier in beef production systems. Animal Feed Science and Technology, 200: 8-16.

Kumar N, UB Singh and DN Verma (1980). Effect of different levels of dietry protein and energy on growth of male buffalo calves. Ind J Anim Sci., 15: 513-517.

Magi E and Sahk M. (2003). Use of herbal medicine principles in local conditions, Agraarteadus, 14: 3, $172-178$.

Mahran G H. (1967). Medicinal plants. Anlgo Egyptian Bookshop, Cairo, ARE.

Malekkhahi M, Tahmasbi A M, Naserian A A, Danesh Mesgaran M, Kleen J L and Parand A A. (2015). Effects of essential oils, yeast culture and malate on rumen fermentation, blood metabolites, growth performance and nutrient digestibility of Baluchi lambs fed high-concentrate diets. Journal of Animal Physiology and Animal Nutrition, 99: 221-229.

March W, 1965 clin. Chem., 11. 624(Pp 967-973).

Marwan A. A, (2008). Nutritional studies on immuno response of new born buffalo calves. M. Sc. Thesis, Fac. of Agric. Ain Shams Univ. Cairo, Egypt.

McIntosh F M, Williams P, Losa R, Wallace R J, Beever D A and Newbold C J. (2003). Effects of essential oils on ruminal microorganisms and their protein metabolism. Appl. Environ. Microbiol., 69: 5011-5014.

Meschiatti MAP, Gouvêa VN, Pellarin LA, Batalha CDA, Biehl MV, Acedo TS, Dórea JRR, Tamassia LFM, Owens FN, Santos FAP. (2019). Feeding the combination of essential oils and exogenous $\alpha$ amylase increases performance and carcass production of finishing beef cattle. J. Anim. Sci., V (97), Issue 1, 456-471.

NRC. (2001). National Research Council. Nutrient Requirements of Cattle. National Academy Press, Washington, DC, USA. 114 Pp.

Ornaghia Mariana G, Rodrigo A C Passettia , Juliana A Torrecilhasa , Camila Mottina, Ana Carolina P. Vitalb , Ana Guerreroc , Carlos Sañudoc, Maria del Mar Campoc, Ivanor N Pradoa (2017). Essential oils in the diet of young bulls: Effect on animal performance, digestibility, temperament, feeding behaviour and carcass characteristics. Animal Feed Science and Technology 234 (2017) 274-283.

Petit, H V.; Flipot PM. (1992). Feed utilization of beef steers fed grass as hay or silage with or without nitrogen supplementation. Journal of Animal Science, 70: 876-883.

Politeo O, Jukic M, Milos M, (2007). Chemical composition and antioxidant capacity of free volatile aglycones from basil (Ocimum basilicum L.) compared with its essential oil. Food Chem., 101 (2007), pp. 379-385.

Ratika K and Singh R K. (2018). Plant derived essential oil in ruminant nutrition -A Review . Int.J.Curr.Microbial.App.Sci 7(5):1747-1753.

Reitman S, and Frankel S. (1957). Calorimetric method for the determination of serum glutamicoxaloacetic and glutamic- pyruvate transeaminase. An.J. Clin. Path., 28:56.

Sajjadi S E. (2006). Analysis of the essential oils of two cultivated basil (Ocimum basilicum L.) from Iran. DARU J. Pharm. Sci., 14 (2006), pp. 128-130. 


\section{Marwan and Mousa}

Santoro GF, Cardoso M G, Guimarães L G L, Salgado A P S, R F S Menna-Barreto, M J Soares (2007). Effectoforegano(Origanum vulgareL.) andthyme (ThymusvulgarisL.) essential oilson Trypanosomacruzi (Protozoa:Kinetoplastida) growth and ultra-structure. Parasitol. Res., 100:783790.

SAS (2001). Statistical Analysis System guide: Version 8.2th. Institute Inc. Cary. Nc. USA.

Schneider B H and P W Flatt (1975). The evaluation of Feeds through Digestibility Experiments the Univ. of Georgia Press Athens, 30602.

Singh B and A L Taparia (1992). Effect of admonition of hill grasses on nutrient utilization by crossbred heifers. Indian. J. of Anim. Nutr., 9, 1: 47-51.

Suppakul P, Miltz J, Sonneveld K, Bigger S W. (2003). Antimicrobial properties of basil and its possible application in food packaging. J. Agric. Food Chem., 51 (2003), pp. 3197-3207

Tassoul M D and Shaver R D. (2009). Effect of a mixture of supplemental dietary plant essential oils on performance of periparturient and early lactation dairy cows. J. Dairy Sci., 92:1734-1740.

Telci I, Bayram E, Yılmaz G, Avcı B. (2006). Variability in essential oil composition of Turkish basils (Ocimum basilicum L.). Biochem. Syst. Ecol., 34 (2006), pp. 489-497

Tozyo T, YoshinIura Y, akurai S K, Uchida N, Takeda Y, Nakai H and Ishii H. (1994). Novel antiumor sesquiter penoids in Ahillea millefolium. Chemical and Pharmaceutical-Bulletin, 42:5,1096-1100.

Vakili A R, Khorrami B, Danesh- Mesgaran M, Parand E. (2013). The effects of thyme and cinnamon essential oils on performance, rumen fermentation and blood metabolites in Holstein calves consuming high concentrate diet. Asian-Aust. J. Anim. Sci., 26: 935-944.

Valero M V, Prado R M, Zawadzki F, Eiras CE, Madrona G S, Prado I N, (2014). Propolis and essential oils additives in the diets improved animal performance and feed efficiency of bulls finished in feedlot. Acta Scient. Anim. Sci., 36: 419-426.

Yang, W Z, Ametaj B N, Benchaar C, Beauchemin K A. (2010a). Dose response to cinnamaldehyde supplementation in growing beef heifers: ruminal and intestinal digestion. J. Anim. Sci., 88: 680 688.

Yang a W Z, Benchaarb C, Ametajc B N and Beauchemina K A. (2010). Dose response to eugenol supplementation in growing beef cattle: Ruminal fermentation and intestinal digestion. Animal Feed Science and Technology, 158: 57-64. 
تأثير زيت الريحان كزيت أساسي على الأداء الإنتاجي لعجول الجاموس، ومقدرتها الهضمية، وبعض القياسات الكيميائية الحيوية للام ومؤشرات التخمر في الكرش الأش

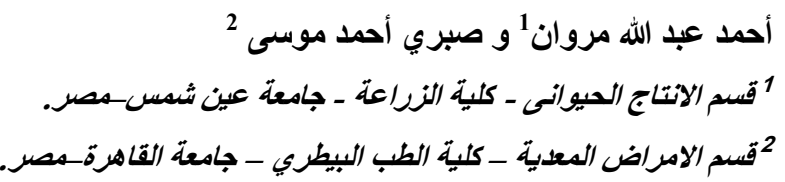

تم إجراء هذه التجربة لدراسة تأثير اضافة الزيوت الطبارة الرئيسية منمثلاً في زيت الريحان إلى علائق عجول الجاموس النامية،

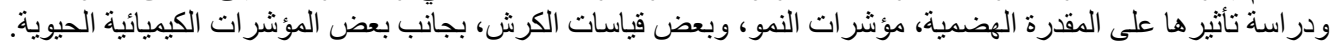

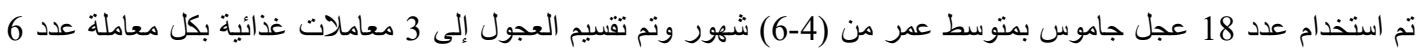
عجول واستمرت التجربة لمدة 15 أسبوع، وكانت المعاملات الغذائية كالتالي: 1- 1 معاملة الكنترول عبارة عن عليقة قاعدية بدون اضافات

2- المعاملة الثانية عبارة عن العليقة القاعدية مضاف إليها 2 مل زيت ريحان / رأس/يوميًا. 3- المعاملة الثالثة عبارة عن العليقة القاعدية مضاف إليها 4 مل زيت ريحان / رأس/يو مئًا.

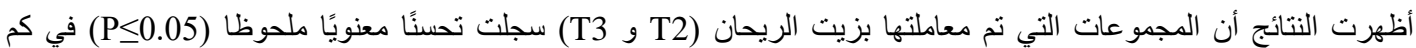

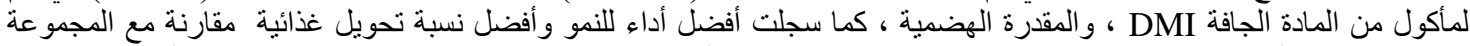

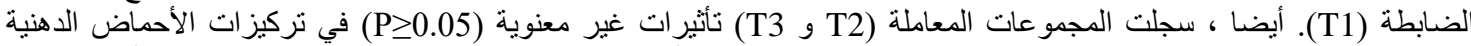

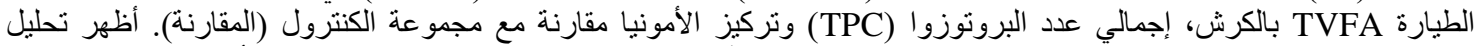

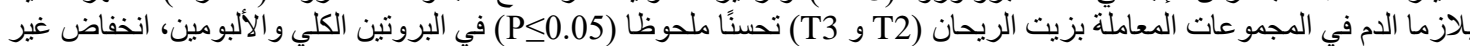

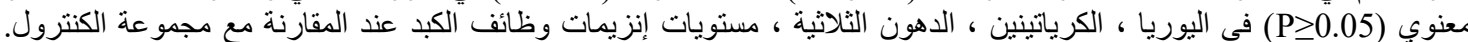

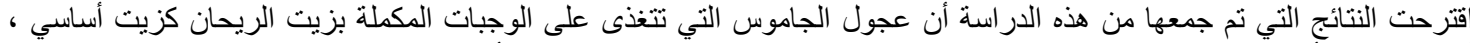

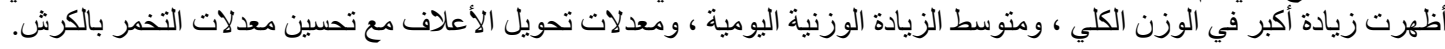

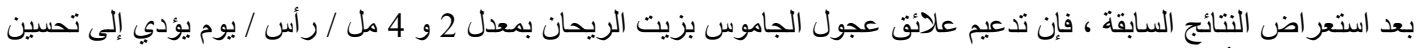

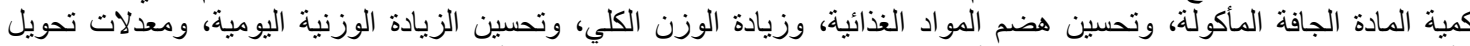

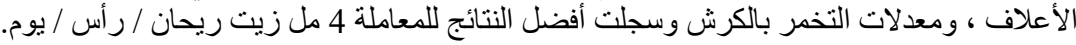

